Article

\title{
Women in China Moving Forward: Progress, Challenges and Reflections
}

\author{
Juhua Yang \\ Department of Sociology, Minzu University of China, 100081 Beijing, China; E-Mail: juhua_yang@ruc.edu.cn
}

Submitted: 5 December 2019 | Accepted: 4 March 2020 | Published: 28 April 2020

\begin{abstract}
While China's socialist revolution has been credited with improving the status of women, gender inequality remains. Drawing on macro data, this article provides an overview of gender equality in China, focusing on labor force and political participation in the past 70 years, particularly since 1978, the onset of socioeconomic reform. Specifically, the article describes, compares, and examines the progress and challenges that women face in accessing economic opportunities and political resources. We find a more equal relationship between male and female when resources are relatively adequate, but that females are disadvantaged when resources are scarce, for example, including representation in more prestigious occupations, higher income, and political positions. These findings illustrate how inequality is maintained and reproduced, and suggest that despite China's progressive socialist agenda, its gender revolution remains 'stalled.'
\end{abstract}

\section{Keywords}

China; gender inequality; labor force participation; political participation; resources; women

\section{Issue}

This article is part of the issue "Left Behind? Women's Status in Contemporary China" edited by Robert Walker (Beijing Normal University, China) and Jane Millar (University of Bath, UK).

(C) 2020 by the author; licensee Cogitatio (Lisbon, Portugal). This article is licensed under a Creative Commons Attribution 4.0 International License (CC BY).

\section{Introduction}

China's socialist revolution has remarkably improved women's socioeconomic status in absolute terms and relative to men-as indexed by women's educational attainment (Li, 2016; Yang \& Xie, 2013), life expectancy, labor force participation (Liu, 2018), and political participation (All China Women's Federation [ACWF], 2019)-largely due to legal and institutional support favorable to gender equality. The gap of education between men and women is disappearing and women have a higher rate of college education among the post-1990-born birth cohort. Women on average even live four years longer than men. Over $40 \%$ of the total workforce in China consists of women, which is among the highest in the world. They are also encouraged to participate in politics. The proportion of female deputies of the 13th National People's Congress (NPC) reached $24.9 \%$ in 2018, 12.9 percentage points higher than that of the first session in 1954, for example.

However, studies have also found that there are still explicit and implicit gaps between men and women in both the public and private arena, particularly so in the labor market (Yang, 2019) and political participation (Shi, 2009; Yan, 2018). Moreover, there are strong voices calling women to return home and leave the workplace to men (Gu, 2013), and discrimination towards women in public arena has become salient with the extensive marketization and urbanization (Ji, Wu, Sun, \& Guo, 2017). In a regime with strong commitment to gender equality, we may wonder what the institutional and structural impediments to the promotion of gender equality in the public arena are, and how women can break through the bottleneck and the glass ceiling in access to better employment and political positions.

This article responds to these questions from the perspectives of state power, cultural regulation, and resource redistribution, focusing on gender equality in economic endowment and political representation in China. Rather than taking a snapshot perspective and focusing on a single indicator of gender equality, this article draws attention to various aspects in the labor market and political participation and compares the performance of men and women in the past 70 years, particularly since the onset of the socioeconomic reform in 1978. It first describes the background of gender relationships in China, 
and then briefly introduces data and methods used in this analysis; this is followed by a sketch of the achievements of gender equality and the analysis of challenges in the workforce. Finally, reflections are offered on the path and mechanism to break through the bottleneck and glass ceiling in the workplace.

We select these two areas because they are domains directly under the control of government in China, especially political participation. In addition to Chairmen Mao's reiterations of the importance of gender equality, Xi Jinping, the General Secretary of the Communist Party of China, stressed that the "pursuit of gender equality is a great cause....Without women's liberation and progress, the liberation and progress of mankind would not be attainable" (Xi, 2015) in his address at the "Global Leaders' Meeting on Gender Equality and Women's Empowerment: A Commitment to Action" in New York in 2015. So, if the government determines to promote gender equality then it has the levers to do so, and we would expect to see the results. This is made more so by the fact that education attainment is largely equal, while the one- or two-child policy means that childcare issues are not as important as they might be in other countries.

Although literature on gender inequality inside and outside China is abundant, this work adds to the current literature in several ways. First and foremost, the approach complements existing studies by examining gender equality in the workplace more comprehensively with historical lenses. Indeed, some empirical studies have already explored gender inequality and women's performance in the workplace (Maurer-Fazio, Rawski, \& Zhang, 1999; Yang, 2019), but focused on a short period of time. Other works (Ji et al., 2017; Wu, 2009) have reviewed gender inequality since the founding of New China or market reform, but they focused on the explanation of gender gaps in the public and private arena. Complementing existing studies, this work provides an overview of the evolutionary trajectory of gender dynamics using empirical data covering the past 70 years. Furthermore, it also considers political participation, an important indicator of gender relationships largely ignored in relevant research. As the World Economic Forum (WEF, 2019) report shows, the situation of gender equality in China worsened in 2019, due to women's lower presentation in politics in addition to the high sex ratio at birth.

\section{Context of Gender Equality in China}

\subsection{Reconfiguration of Institutional Norms}

China is well known for its long history of gender inequality. Women were dependent on their fathers, husbands and children in different life stages under the traditional patriarch system, which defined the gender relationships and designated different roles for men and women in public and private arenas (Yang, 2010). Within this cultural discourse, there was a clear demarcation between men and women in the division of labor and role expectations.

Since the founding of the People's Republic of China (PRC) in 1949, however, "times are different, and men and women are equal" ("Chairman Mao and Chairman Liu," 1965). The Communist regime, with its strong commitment to gender equality and state power (Wu, 2009; Zuo, 2005), vigorously advocated gender equality in many ways. The political commitment was bolstered by the Constitution of the PRC, by various laws, public policies (e.g., the 1988 Regulations on Labor Protection of Female Employees, the 1992 Law of the PRC on the Protection of Rights and Interests of Women, the 2008 Employment Promotion Law, and the Law on Land Contract in Rural Areas, from 2002-2018), and practices in guaranteeing women's rights in all aspects and providing public childcare service to emancipate women from the household. Article 48 of Constitution of PRC, for example, states that:

Women in the People's Republic of China enjoy equal rights with men in all spheres of life, in political, economic, cultural, social and family life. The state protects the rights and interests of women, applies the principle of equal pay for equal work to men and women alike and trains and selects cadres from among women. (The Central People's Government of the PRC, 2005)

The interplay and interaction of political, legal and cultural shifts have all laid down a foundation, from topdown, for gender equality in the workforce in China.

Consequently, urban and rural women were gradually liberated from traditional patriarchal systems and joined the workforce in the early years of New China. The rise of the service industry in the 1960s further alleviated discrimination against women in employment. Indeed, female labor force participation is one of the most important breakthroughs against thousands of years of traditional division of labor. 'Iron girls' were the representation of the new types of gender division of labor in the 1960 s and 1970s. While the new pattern has a negative effect on women because it solidifies, rather than challenges, traditional gender roles (Jiang, 2012; Jin, 2006; Zuo, 2005), the role of a 'social person' definitely helps women break free and to move towards achieving equality with men in rights and obligations (Jiang, 2012).

However, we should also acknowledge that since China's advocacy and practice of gender equality largely results from the communist commitment to emancipate women from feudalist tradition (Li, 1997), the promotion of gender equality may have intrinsic constraints and simply be the political discourse of the ruling party. During the first 30 years of New China, gender equality was supported by both an equal gender ideology and grass-root practice, but in the subsequent 40 years, the dominant position of the government in the gender dis- 
course has given way to the market. However, the market, for the purpose of making money, allied with the traditional gendered culture that highlights male superiority, has changed the dominant narratives of gender relationships, deviating from the state will of gender equality (Wu, 2009).

\subsection{Transformation of Socioeconomic and Demographic Structure}

Structural change of the Chinese society began in the 1950s, but the foundation of industrialization was very weak. Until 1978, China was still an agricultural country. Since then, however, it has experienced a dramatic structural transformation, moving from a closed regime to an open country, from a planned economy to a market economy, from an agricultural society to an industrialized and urbanized society, from high levels of illiteracy, especially among women, to universal education, and from many children to one or two children in each family (Yang \& $\mathrm{He}, 2014)$. Changes in these structural forces jointly generated a new round of shocks, from bottom-up, to traditional gender norms, both positive and negative.

On the positive side, the most important structural change with respect to gender equality is the enhanced level of education, addressed in another article in this volume. Simply speaking, the implementation of the Compulsory Education Law and the expansion of college education have benefited women more than men. Female illiteracy among those aged 15 and above was over $90 \%$ in 1949 but reduced to $7.3 \%$ in 2017; with regard to college enrollment, women accounted for less than $20 \%$ in 1949 , but $52.5 \%$ in 2017 (ACWF, 2019). The convergence of education between the two sexes and the higher proportion of college education of women than men among post-1990-born birth cohort will have endowed women with better formal human capital. This enables women to better participate and compete with men in the public arena and has also changed their preferences towards work and family, which in turn allows them to become more independent, autonomous and self-reliant. Consequently, a more equal gender relationship could be cultivated.

Meanwhile, the influx of foreign capital and the development of manufacturing industry since 1978 have speeded the pace of industrialization and urbanization. Geographic mobility has been spurred since the early 1980 s by the desire to pursue a better life and by relaxation of the household (hukou) registration system. The number of rural-to-urban migrants increased from 6.57 million in 1982 to 245 million in 2017, contributing greatly to the rapid growth of urbanization, which was $10.6 \%$ in the early 1950 s, $20 \%$ in 1978 and $59.6 \%$ in 2018 (The Central People's Government of the PRC, 2019). Large-scale migration and urbanization have also facilitated the shift in economic structure from agriculture to industry, and from industry to service sectors. In 1952 , the share of agriculture in GDP was $50.5 \%$, and agriculture absorbed $83.5 \%$ of the employed population. In 2018, however, the share in GDP accounted for by agriculture, industry and service sector was 7.2, 40.7 and $52.2 \%$ while the corresponding proportions of employment were $26.1,27.6$ and $46.3 \%$ respectively. What these numbers simultaneously hint at and conceal are a growth in opportunities for women to pursue a career outside the home and away from the land.

The implementation of the restrictive fertility policy, initiated in 1980 and ended in 2015, also played a role in reshaping gender relationships. Whereas in 1953 families tended to have six children, this number fell to 2.7 in 1979 (Yang, 2017) and 1.6 in 2018 (UNDP, 2019). While acknowledging the controversy surrounding this policy and the complexity of determining its overall effect, the rapidly decreasing fertility has had profound implications for gender equality. By reducing the number of children and thereby further emancipating women from childbearing and childrearing, it has enabled women to devote more time to work, pay more attention to selfimprovement and to pursue their own life goals (Zhu \& Li, 1997).

However, since China's process of modernization is compressed and its modernity is incomplete (Chang, 2014), the political efforts at promoting gender equality may also be compromised. During the process of marketization, traditional gender roles have revived and to some extent been further strengthened (Gu, 2013), increasing women's vulnerability in the workplace (Song, 2011). The emphasis on replacing the planned economy by the market economy and the subsequent reform of state-owned enterprises was to maximize productivity, and women were regarded as being less productive and more expensive due to their role of motherhood (Du \& Dong, 2013; Yang ,2019; Zhang \& Hannum, 2015). As a result, women were laid-off in disproportionate numbers, and almost all public childcare facilities were closed (Yang, 2018). These changes frustrated political and legal efforts to promote gender equality and undermined the benefits of higher human capital and increased economic opportunities, causing China's gender revolution, as in some countries in the West, to stall (England, 2010; Hochschild, 1989).

Simultaneously, the mass media, catering to mass culture and the market economy with reality shows, advertisements and other print media, has served to exaggerate differences between men and women in terms of personality, appearance, capacity, division of labor and family roles. In the name of 'modernity' and 'modern fashion' (Gu, 2013; Liu \& Zhang, 2013), the traditional image of women and female roles is praised and male supremacy maintained and highlighted.

Also, there is a 'spillover effect' of the disadvantage of women in public and private spaces. In China, there was historically a clear gender boundary in the division of labor (Stockman, Bonney, \& Sheng, 1995). Chinese women do considerably more housework than their husbands (Yang \& Li, 2014), indicating that the strong socialist ide- 
ology of gender equality in work has not successfully promoted normative ideas regarding equality in the division of housework. The lingering of these traditional gender roles has a direct negative effect on women's wage income (Qing, 2019) which may partly explain why women's strong attachment to the labor force has not correspondingly altered the balance of power in the household.

Given these institutional and structural shifts and prior research, we may expect both progress and stagnancy or even retrogression in gender relationships, more so in the era of market-oriented reform than in the period of a planned economy.

\section{Methodology}

\subsection{Data}

To provide an overview of gender equality in China, this article draws on macro data and, when available, survey data to compare men and women's performance in economic and political areas. Macro data mainly include: data from statistics yearbooks issued by the National Statistical Bureau (NSB); aggregated data from the 1982, 1990, 2000 and 2010 population censuses, and the 1995, 2005 and 2015 One Percent Population Survey, also known as the Mini-census, conducted at the midpoint between two censuses; and data issued by international organizations. Existing literature is also drawn on to help interpret the statistical evidence.

Since various sources of data are collected for different purposes, they may be inconsistent and not entirely compatible with each other. However, these inconsistencies should not introduce bias or pose serious problems since, if the data are over-or under-reported, they tend to be so for both males and females and hence not affect the relativities. Moreover, when more than one source is available, we use that which is generally regarded by scholars to be more reliable.

\subsection{Analytical Approaches and Strategy}

While this article does not employ sophisticated statistic methods, it does employ a comparative and historical perspective in exploring the patterns of gender equality in the workplace. Across various cultures and societies, the potential tensions of gender relationships can be reduced to two factors of demography and social mobility: the level of inequality itself and the processes determining the locations of men and women in the social hierarchy. This article focuses on the former, comparing men and women's access to resources, opportunities and outcomes in the labor market and political arena. Such a comparison serves two purposes: to provide an overall picture of gender equality and to lay down a foundation for a conceptual framework to explain continuing gender equality in China. While it would be desirable to compare gender dynamics between rural and urban areas, or especially to focus on urban areas, given tremendous dis- parity in rural and urban development in China, this is prevented by lack of data.

Two caveats should be noted. First, this article reports only those indicators of gender equality that are most appropriate in the Chinese context given data availability. Secondly, the definition of gender equality is inevitably somewhat fuzzy since absolute equality may be neither appropriate nor attainable. Therefore, gender inequality is taken to be a relative concept and measured as difference, rather than in terms of discrimination.

\section{Labor Force Participation: Progress and Challenges}

From a 70-year perspective, prominent improvements are clearly evident in the relative position of women, but since the early 1990s, the onset of marketization, women have faced more challenges in the workplace.

\subsection{Labor Force Participation}

A comparison of the labor force participation rate for men and women aged 15 to 64 is an important indicator of gender equality. In most societies, women account for over one-third of the total labor force, and there is a positive linkage between gender equality and economic growth (Khayria \& Feki, 2015; Lewis, 2011; Pagés \& Piras, 2010). In addition, women in the industrialized world contribute an average of about $50 \%$ to national production through non-remunerated work while those in the developing world contribute between 60 and $65 \%$ (Meleis \& Lindgren, 2002). In China, women contribute about $41 \%$ to GDP, higher than in most other countries or regions (Statista, 2020), without considering unpaid work.

Women's high contribution to GDP is linked to their high rate of employment, which was just $7.5 \%$ in 1949 but rose to $32.9 \%$ by 1978 , one of the highest in the world. During Mao's era, women labored shoulder-toshoulder with men, which put many women on the same level as men for the first time ever in China (Vanham, 2018). In the early years of socioeconomic reform, female employment rate kept rising; it was over $70 \%$ in 2000 , about 10 percentage points higher than that of the world average (Bao, 2004). Whereas only about two hundred thousand women were employed in 1949, by 2017 the absolute size of the female labor force was 340 million (ACWF, 2019). However, female labor participation rate has declined in recent years. Figure 1 depicts the changing trajectory of labor force participation rate for men and women from 1990 to 2017, showing a monotonic decline for both sexes, but faster for women than for men. By 2017 the participation rate for women was 14 percentage points lower than men.

The decline of labor force participation since the early 1990s might be related to longer years of education for the general population who enter the labor market at much older ages, and the reclassification of 'work' - some people may conduct business at home and consequently are not included as 'working' (Liu, 2007). 


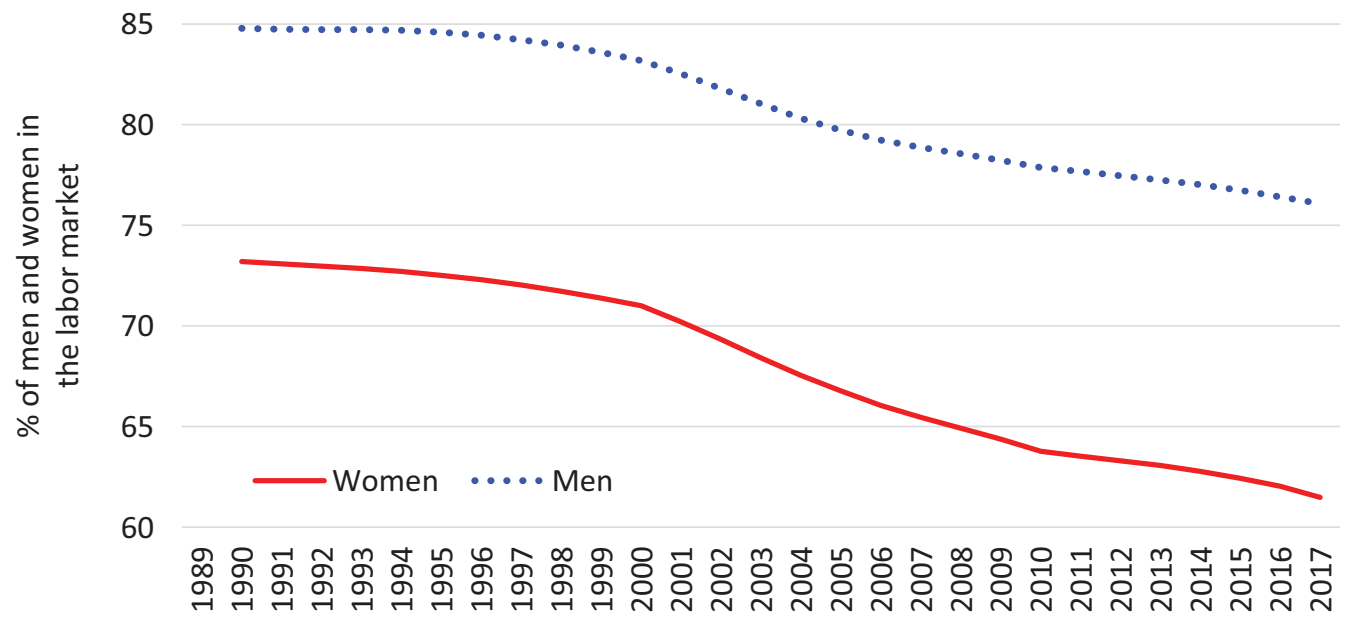

Figure 1. Labor force participation rate by gender: China 1990-2017. Labor force participation rate, male (percentage of male population ages 15+; modeled ILO estimate). Source: The World Bank (n.d.).

More importantly, however, was the differential layoff of women by employers in the market reform (Song, 2011).

\subsection{Occupational Prestige}

The distribution of occupations between men and women has changed over time with the proportion of women occupying the highest prestige jobs, as the heads of government, party organizations, state-owned enterprises, and scholastic institutions, increasing by 14 percentage points, from $10.4 \%$ to $24.9 \%$ between 1982 and 2015 (see Table 1).

Similarly, the proportion of women employed as professionals has increased from $38.3 \%$ to $51.6 \%$.

Table 1. Occupations by gender: China 1982-2015 (in percentage).

\begin{tabular}{|c|c|c|c|c|c|c|c|c|}
\hline & $\begin{array}{c}\text { Leader of } \\
\text { government, } \\
\text { party } \\
\text { organization, } \\
\text { enterprises, } \\
\text { and institutions }\end{array}$ & Professionals & $\begin{array}{c}\text { Office } \\
\text { workers }\end{array}$ & $\begin{array}{c}\text { Commercial } \\
\text { service } \\
\text { persons }\end{array}$ & $\begin{array}{c}\text { Agriculture } \\
\text { or related } \\
\text { persons }\end{array}$ & $\begin{array}{l}\text { Production and } \\
\text { transportation } \\
\text { equipment } \\
\text { operators } \\
\text { and related } \\
\text { personnel }\end{array}$ & Other & Total \\
\hline \multicolumn{9}{|c|}{1982} \\
\hline $\mathrm{F}$ & 10.4 & 38.3 & 24.5 & 47.5 & 46.8 & 35.4 & 41.7 & 43.7 \\
\hline M & 89.6 & 61.7 & 75.5 & 48.9 & 53.2 & 64.6 & 58.3 & 56.3 \\
\hline \multicolumn{9}{|c|}{1990} \\
\hline $\mathrm{F}$ & 11.5 & 45.3 & 25.7 & 51.1 & 47.9 & 35.7 & 42.5 & 45.0 \\
\hline M & 88.5 & 54.7 & 74.3 & 50.0 & 52.1 & 64.3 & 57.5 & 55.0 \\
\hline \multicolumn{9}{|c|}{2000} \\
\hline $\mathrm{F}$ & 16.8 & 51.7 & 30.3 & 50.0 & 48.5 & 33.4 & 36.2 & 45.3 \\
\hline M & 83.2 & 48.3 & 69.7 & 50.0 & 51.5 & 66.6 & 63.8 & 54.7 \\
\hline \multicolumn{9}{|c|}{2005} \\
\hline $\mathrm{F}$ & 21.7 & 49.4 & 31.8 & 48.9 & 49.7 & 32.5 & 34.9 & 45.4 \\
\hline M & 78.3 & 50.6 & 68.2 & 51.1 & 50.3 & 67.5 & 65.1 & 54.6 \\
\hline \multicolumn{9}{|c|}{2010} \\
\hline $\mathrm{F}$ & 25.1 & 51.1 & 33.0 & 51.7 & 49.2 & 31.6 & 37.5 & 44.7 \\
\hline M & 74.9 & 48.9 & 67.0 & 48.3 & 50.8 & 68.4 & 62.5 & 55.3 \\
\hline \multicolumn{9}{|c|}{2015} \\
\hline $\mathrm{F}$ & 24.9 & 51.6 & 36.2 & 43.4 & 48.6 & 31.0 & 34.4 & 42.6 \\
\hline M & 75.1 & 48.4 & 63.8 & 56.6 & 51.4 & 69.0 & 65.6 & 57.4 \\
\hline
\end{tabular}

Note: M stands for Male, F stands for Female. Sources: Data from 1982-2000 from NSB (2003, Table 4-8), data from 2005 from NSB (2007, Table 5-3), data from 2010 from NSB (2012, Table 3-3), data from 2015 from NSB (2016a, Table 5-4). 


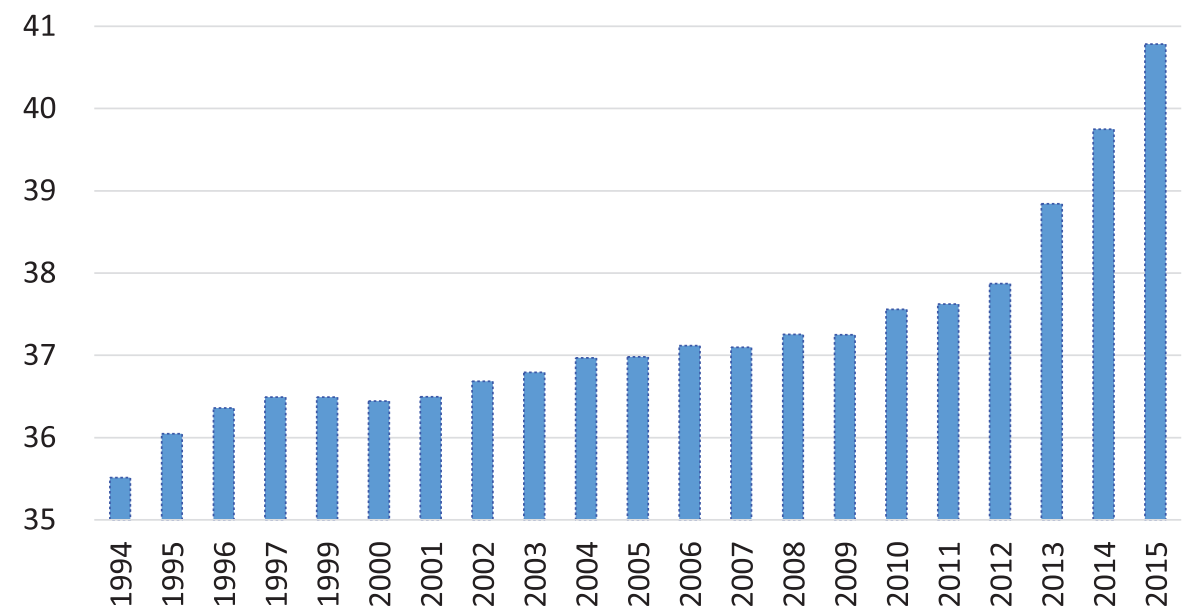

Figure 2. Percentage of women employed in state-owned enterprises: China 1994-2015. Source: Calculated from NSB (2016b, Tables 1-17 and 1-23).

Conversely, the proportion of women in relatively lower status jobs, e.g., commercial service industry, decreased from $47.5 \%$ in 1982 to $43.4 \%$ in 2015 , and the proportion of women as production and transportation equipment operators and related personnel decreased from $35.4 \%$ to $31.0 \%$ over the same period. State-owned enterprises remain highly privileged and prestigious even after China's economic reform. The proportion of female employees in this sector has increased notably since 1994 (Figure 2), while those employed in the sector as professional and technical personnel increased even more from 39.1\% in 1982 to $48.6 \%$ in 2017 (ACWF, 2019).

Having acknowledged the substantial progress of gender equality, however, we should also recognize that the gender gap remains salient in higher prestigious occupations. As shown in Table 1, only a quarter of the heads of government, party organizations, state-owned enterprises and scholastic institutions are women. The reasons for the remaining inequality are inevitably complex, a combination of demand and supply side factors both mediated by persistence of traditional gender norms, to be described in other articles in this issue.

\subsection{Wage Income}

Bases on the analysis of Cotter, DeFiore, Hermsen, Marsteller Kowalewski, and Vanneman (1997), in the USA it would be expected that the improved work opportunity and enhanced occupational prestige for women will have led to an increase in women's wages and a reduction in the gender wage gap. For a long period in the second half of the 20th century, the ratio of women to men's income in China was more favorable than in most other countries (Liu, Meng, \& Zhang, 2000), with women in the same positions as men tending to receive equal pay (particularly in state-owned organizations). However, this favorable situation disappeared in the reform era. Data from the China Women Social Status Survey shows that women's income rose substantially from 1086 Yuan in 1990 to 11987 Yuan in 2010 (see Figure 3). However, as Figure 3 also illustrates, while the wage income of the two sexes has grown monotonically over time, the pay gap has widened. Corresponding to relatively low occupational status jobs, women have experienced slower wage income growth than men.

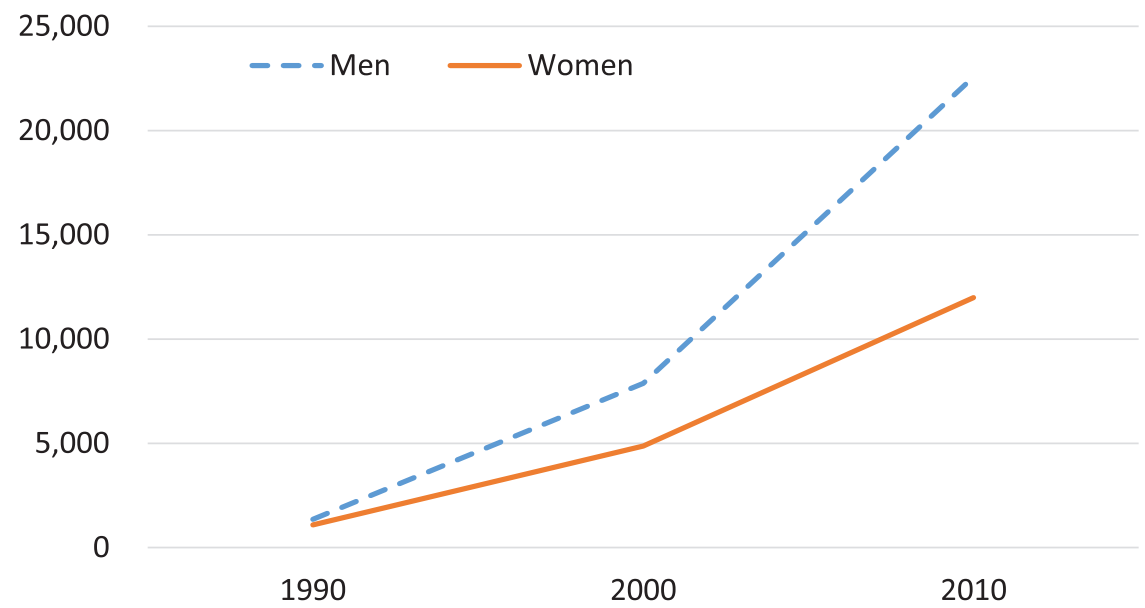

Figure 3. Wage income by gender: China 1990-2010. 
The increasing gender wage gap is not unique to China. According to WEF (2019) report, while gender equality has made progress over time, the gender ratio in income has retreated from $58.1 \%$ in 2018 to $57.8 \%$ in 2019 globally, and it is expected to take 257 years to close the gender gap, longer than estimates in previous WEF reports. In context with more equal gender ideology, the gap is narrower, but even in the most equal and developed countries or regions in the world, women earn only $90 \%$ that of men; controlling for the potentially confounding effect of education, work experience and other factors on income does not make the gap go away (Bowlus, 1997).

Figure 4 shows the ratio of female to male monthly income in urban areas between 1978 and 2015. While the ratio fluctuated, women consistently earned less than men throughout the entire period; and while the gap was gradually closing prior to 1988 , it subsequently continued to widen until a slight rebound in 2015. In 1978, women's income was $79 \%$ that of men, rose to $84 \%$ in 1988 , dropping thereafter to $63 \%$ in 2014 . In the transition from a socialist to market economy, the emerging market sectors tended to favor men over women (Shu \& Bian, 2003), while the educational enhancement of women does not seem to have translated to a reduced gender wage gap (Ji et al., 2017).

\section{Political Presentation: Progress and Stagnancy}

Political participation is another, or even a more important, indicator of gender equality, and a channel through which to promote other aspects of gender equality. Since the establishment of New China, great importance has been attached to guaranteeing equal political rights between women and men. Women's rights of suffrage, being elected and the management of state affairs have been legally guaranteed since the early 1950 s under the socialist democratic politics with Chinese characteristics.
Women have been provided new opportunities for participating in politics, and the level of their participation in state governance and social affairs at the local level has generally improved but with some exceptions.

As mentioned above, the Constitution of the PRC specifically guarantees women's equal rights with men in political life and protects the rights and interests of women in training and selecting cadres. Under this overarching framework, a number of laws, legislations or regulations related to ensure women's political rights are stipulated, including the Law of the PRC on the Protection of Rights and Interests of Women (1992). Currently, the China National Program for Women's Development (2011-2020) covers seven areas, including economic and political participation. Additionally, China has signed many international conventions aimed at addressing gender inequality, the Convention on the Elimination of all Forms of Discrimination Against Women which China ratified in 1980 (Hearle \& Hu, 2019), for example.

In 1990, the National Working Committee on Children and Women under the State Council was founded, which is the key body or political organization mandated to "organise, coordinate, guide, supervise and urge departments concerned in promoting gender equality and women's development" (State Council Information Office, 2015). Also, the ACWF, established in 1949 , has long been the major organ that aims to promote women's rights and gender equality at all levels. While it does not have the rights to make policies or regulations, it has the rights to push agendas, and propose changes to existing policies and opposition to policy proposals (Hearle \& Hu, 2019).

\subsection{Political Participation at the Top Level}

Since 1949, China's communist regime has showed great support for gender equality, and women's so-

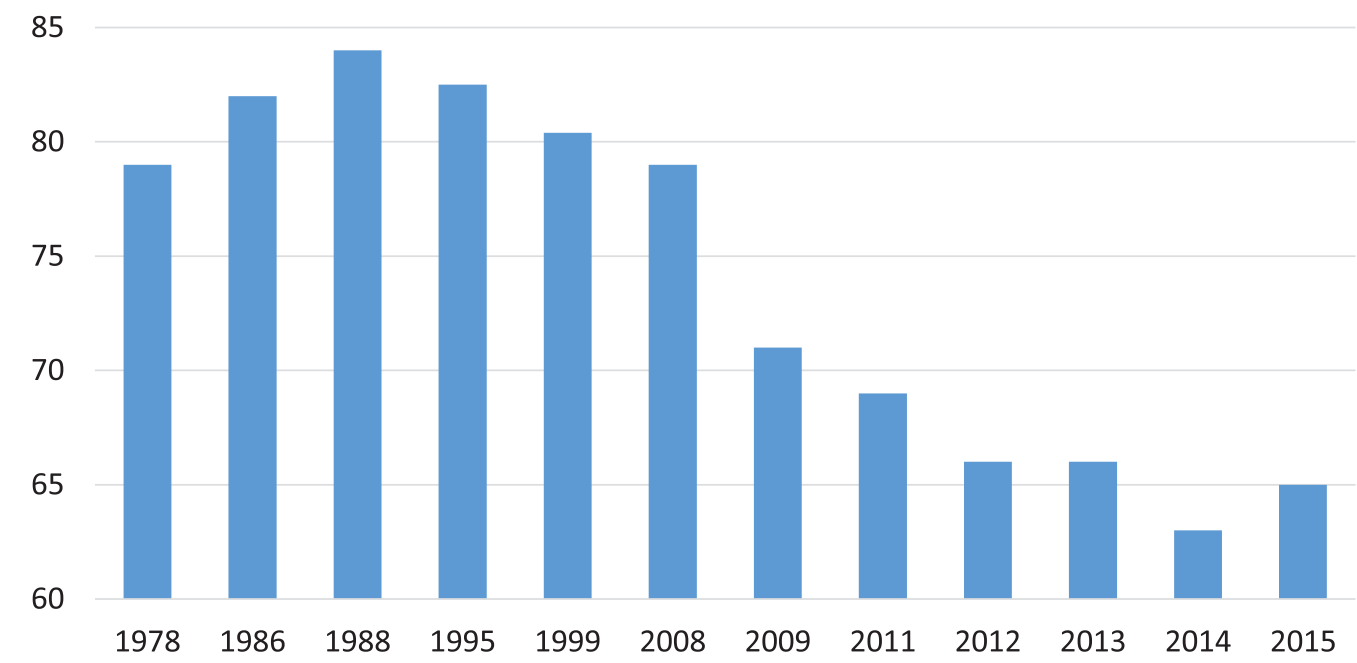

Figure 4. Ratio of women's income to men's income: China 1978-2015. Due to different sources of data, the gender wage gap differs. Sources: Data from 2008-2015 from WEF (2019); other data compiled by the author. 
cial and political status has in many aspects improved, although great variation exists. Membership of the Chinese Communist Party is the fundamental form of political participation, and being a member of the ruling party (and other democratic parties) is the first step and prerequisite for getting promoted in the workplace (namely in government agencies and state-owned enterprises), for further political participation, and the most effective way of directly partaking in politics. Hence, women's share in the ruling party is a good indicator of the level and extent of their political involvement, and thus of the degree of gender equality. In 2018, female party members accounted for $27.2 \%$ of total members, a 16.7 percentage point increase compared to 1956 (ACWF, 2019). The increase of female party members of the Communist Party of China and other democratic parties has also led to a higher participation rate of women in the NPC, the Central Committee of the Communist Party of China (CCCPC), and the Chinese People's Political Consultative Conference (CPPCC), the top level and most influential political participation.

The CCCPC is the core power organ or the most powerful political organization of China. It holds a national congress every five years, leads the work of the whole party and decides the appointment and removal of personnel at the national level. The membership in CCCPC is an important means of giving women voice and promoting gender quality. As Figure 5 shows, the absolute number of female members in the CCCPC increased from 170 in 1956 to 378 in 2017; while the proportion fluctuates over time, it increased from $4.7 \%$ in 1956 to $7.94 \%$ in 2017 albeit with notable fluctuations.

The share of female representatives of the NPC has also grown noticeably. The NPC is an important platform for achieving the goal of sovereignty belonging to the people and being a deputy on it allows women to effectively engage in politics. Deputies gather once a year to discuss and make decisions on important public affairs. At the first NPC in 1954, there were 147 female deputies, accounting for $12 \%$ of the total (see Figure 6). By the fourth session held in 1975, the number of female deputies had risen to 653 , accounting for $22.6 \%$, a figure that has remained largely unchanged in subsequent sessions. In the 13th NPC held in 2018, there were 551 female deputies, accounting for $24.9 \%$ of all deputies, double the percentage in 1954. Figure 6 also shows the proportion of female deputies in CPPCC. While fluctuating, the proportion of women has increased over time, from $6.1 \%$ in 1954 to $20.4 \%$ in 2018 , a 14.3 percentage point increase during this time span. Indeed, many women's political participation is realized through the channel of the CPPCC.

The increase of the absolute number and relative share of female deputies of the CCCPC, the NPC and the CPPCC points to the increasing engagement of women at a national level and, in each province, the proportion of women in these organizations has also increased over time. Of course, we need to first ask where the power lies in the Chinese political system if we want to assess Chinese women's participation in politics. While the NPC might not be the best benchmark to evaluate women's political participation, it offers them exposure to political opportunities and recognition by the general population. It is a symbol of progress compared to the situation 70 years ago. Of course, the progress of gender equality in political area is not as fast as we would expect.

\subsection{Political Participation at the Local Level}

As the ruling party, the Chinese Communist Party attached great importance to the training and selection of female cadres and the development of female party members at the local level, and all reports of party congresses since 1990 have clearly demanded attention to be paid to these issues. The report of the Nineteenth

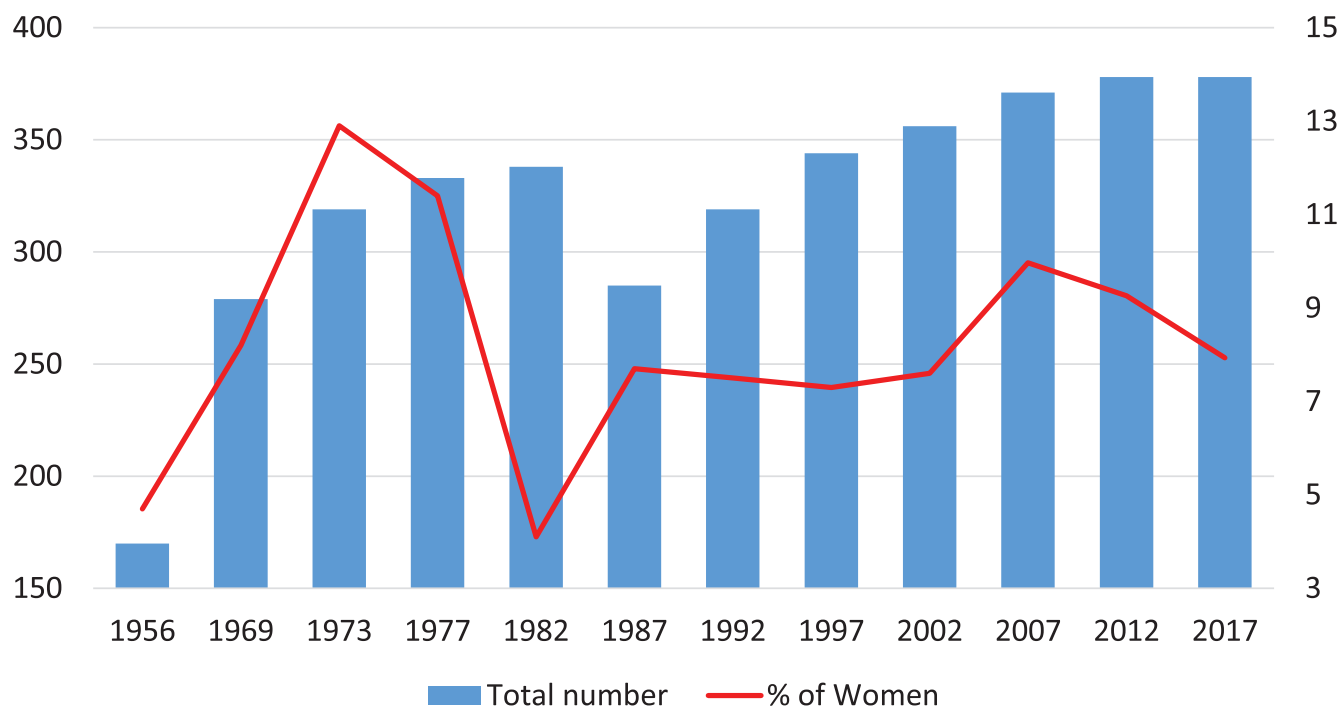

Figure 5. The number and percent of female member in the CCCPC: China 1956-2017. Sources: NSB (2012, Table 7-1) and "List of members of the 19th Central Committee" (2017) for the 2017 data. 
25

20

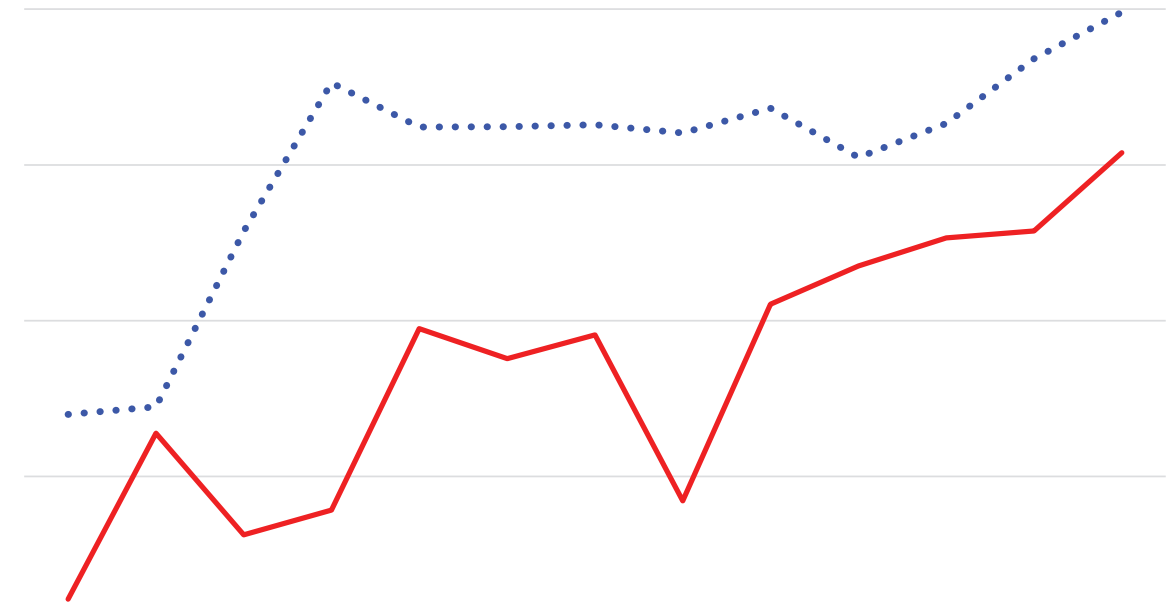

5

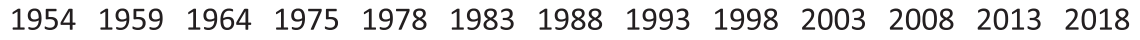

— $\%$ of women as CPPCC members $\quad$....\% of women as NPC deputies

Figure 6. Percentage of female deputy in the NPC and CPPCC: China 1954-2018. Sources: "The proportion of women in CPPCC and NPC has reached a new high" (2018) and NSB (2012, Tables 7-1 and 7-2) for the 2013 and 2018 data.

National Congress of the CCCPC in 2018 emphasized that the work of training and selecting female cadres, ethnic minority cadres and non-Party cadres should be well coordinated.

Consequently, the number of female cadres in Party and government organs increased from 422,000 in 1978 to $1,906,000$ in 2017 , accounting for $26.5 \%$ of the total numbers of cadres today. In 2017, women also constituted $52.4 \%$ of new civil servants recruited by the central government and its directly affiliated institutions, and $44 \%$ of persons recruited by local governments. In 2018, the proportion of women in leading bodies of public institutions nationwide was $22.2 \%, 1.6$ percentage points higher than that in 2015 (ACWF, 2019).

However, the rising share of women in these top organs of state and local levels should not disguise the underrepresentation of women in the policymaking process. Women comprise less than $30 \%$ of members of the ruling party, and the number of female deputies on the CCCPC, the NPC and the CPPCC remains very low. In certain years, the proportion of female deputies and members has actually fallen. In 2003, for example, women accounted for only $20.2 \%$ of the 10 th NPC membership, 1.57 percentage points lower than that of the 9 th congress. More importantly, not only are many fewer women than men appointed to the Political Bureau of the CCCPC, but also none of current seven members of the Standing Committee of the Political Bureau, the most powerful institution, is female. Although women appear to have equal rights to vote and stand for election, they are still a minority in the formal political system. At the lowest level of government, arguably the level most noticeable in people's lives, women accounted for only $5.8 \%$ of village directors (including vice directors) and $5.4 \%$ of female village Party secretaries (including vice secretaries) according to the third China Women Social Status Survey conducted in 2010 (Song \& Zhen, 2013).

So, it is clear that there is a disjuncture between policy rhetoric and women's presentation in the political arena. Indeed, the WEF reports in recent years show that China's gender equality has deteriorated, and one of the two most important indicators responsible for the lowering ranking is women's low representation in politics. Political position, arguably the most valuable resource since it generates other kinds of resources, has been historically and, to a less extent, currently, controlled and possessed by men. Women used to be taught not to access it and had no access to it. While all parties in China today allegedly welcome female members, women continue to have limited access and opportunity to both higher and lower levels of political positions. Even when opportunities present, women may not be willing or able to take them due to the 'spillover effect' of heavy domestic duties that continue to be borne by women since gender stereotypes prioritizing women's reproductive roles as dutiful wives over their productive role (Hearle \& $\mathrm{Hu}$, 2019) remains pervasive in China.

\section{Summary, Discussion and Reflection}

Both macro and micro data paint a picture of progress and challenges in gender relationships. Generally speaking, Chinese women have moved forward over the last 70 years, making salient progress in the public domain with the gender relationship becoming more equal economically and politically. This is apparent in the relatively high rate of female labor force participation, in the influx of women into more prestigious occupations, in substantially increased wage income, and in the growth in political representation in the institutions of 
government, if we examine gender relationship from a 70-year perspective.

However, significant gender gaps have also occurred in the workplace in the past 70 years, and further widened in the reform era. While both men and women have experienced a reduction in employment rate, women's decline is more pronounced than for men. The varieties of occupations open to women is limited, particularly those with higher prestige. While women's wage income has risen over time, men's income has increased much faster. Their share in top political positions is only one-fifth to one-fourth that of men, and less than onethird in lower level of political positions. Consequently, the gender gap in the workplace is persisting, and in some indicators, widening. In other words, although most of the indicators examined here have been going in the right direction, marketization has had an adverse impact, especially regarding employment. We have witnessed progress in the political arena, but it is not a very good picture overall-not only are women missing at the 'top,' but they are also missing at the 'bottom' (in the villages).

The falling employment rates, the rise of wage income, and the fluctuating rate of political participation may mirror period effects resulting from industrialization, modernization and marketization, while the existing and enlarged gender gap found in this article may reflect the continuation of traditional sex roles rooted in the patriarchal system resurrected and strengthened by marketization. It is clear that women substantially enhanced human capital, available time and personal space due to the lower birth rate, and improved capacity in various ways neither bring them corresponding occupational prestige or income, nor political positions. The general pattern is that a more equal gender relationship is found between men and women when resources (e.g., education and health) are relatively adequate, particularly when the resources can be effectively controlled or distributed by government, but that a female disadvantage emerges when resources are scarce, e.g., more prestigious occupations, higher wage and political positions.

Indeed, although during the past 70 years China has consistently advocated and practiced gender equality in a top-down pattern by means of legislation and public policies, these regulations have tended to be guidelines. During the period with a planned economy it proved possible to realize the political desire for greater gender equality through the exercise of authoritarian state power. Since such norms were not internalized by the general population in Mao's era, the ideology of gender equality has given way to profit-seeking behaviors during the era of marketization. Moreover, when facing employment pressure in the early stage of market reform, scholars, social activists and even government officials repeatedly proposed that women should go home to take care of the family and leave market jobs to men. This points to a departure from, indeed even a corruption of, the ideology of gender equality which is now seen to be conditional on the premise of not harming the interests of men. The outside world must still belong to men, and it could also belong to women today, depending on the acceptance of men. This male-centered conditionality has rendered the so-called 'equal division' between the two sexes to be more of a slogan or simply a politically correct discourse than a reality.

Limited supply of publicly funded childcare service for children under the age of three is also a major deterrent to women's performance in the labor market. With market-oriented reform, this service has almost totally disappeared (Yang, 2018). While private 'childcare' services have flourished in recent decades, it is either too expensive to be affordable to working class families, or does not provide daily-based childcare service-they mostly only provide early child education or development courses on weekends and holidays. Women have to work a "second shift" (Hochschild, 1989), and shoulder the double burden of paid and unpaid domestic work. This renders women's daily total work hours much longer than men's, creating greater tension between work and family responsibilities. Consequently, they may either have to exit the labor market for reason of family responsibilities or be unable to devote as much time to work as men, which negatively affects their job performance. Moreover, given the universal two-child policy regime, employers may fear that women will take maternity leave twice, exacerbating discrimination toward women in the workplace (Kang \& Lv, 2016).

Hence, further improvements of gender equality cannot simply rely on women's subjective initiatives; efforts at all levels and by all stakeholders are important in promoting gender equality in the workplace in China. For example, the government should take more concrete steps to change traditional gender roles in both the private and public arenas and promote equally paid paternity and maternity leave. Also, more concerted efforts should be made to encourage enterprises to adopt family-friendly work arrangements, and reduce discrimination towards women in terms of recruitment, promotion, and in other aspects of employment practice. Moreover, safe public childcare services for children under the age of three should be revived in order to alleviate childrearing penalties and work-family conflicts, especially for the mother, in addition to encouraging the market to provide childcare services to meet the diverse needs of families. Through these efforts, more equal gender norms and practices in the workplace could be realized, which in turn would stimulate women's work potential and generate a 'gender-equality dividend.' This will not only be a powerful engine for a new round of economic growth, but also a driving force for an inclusive and sustainable development, when the current 'demographic dividend' disappears.

\section{Acknowledgments}

This work is supported by the China National Natural Science Foundation (Project No. 71673287), and the 
Major Project of National Social Science Foundation of China (Project No. 17ZDA122). I would like to thank Dr. Robert Walker and Jane Millar for their insightful suggestions and careful editing of the article. I would also like to thank reviewers for their valuable comments. Further, I would like to thank Susu Wang for compiling some data used in this article.

\section{Conflict of Interests}

The author declares no conflict of interests.

\section{References}

All China Women's Federation. (2019). White book of equal development and sharing: The development and progress of women's cause in the past 70 years in New China. Central People's Government of the PRC. Retrieved from http://www.gov.cn/zhengce/ 2019-09/19/content_5431327.htm

Bao, J. H. (2004). The history, current situation and prospect of female labor force participation. Labor \& Social Security World, 3, 28-29.

Bowlus, A. J. A. (1997). Search interpretation of malefemale wage differentials. Journal of Labor Economics, 15(4), 625-657.

Chang, K. S. (2014). Individualization without individualism: Compressed modernity and obfuscated family crisis in East Asia: Transformation of the intimate and the public in Asian modernity. Leiden: Brill.

Cotter, D. A., DeFiore, J., Hermsen, J. M., Marsteller Kowalewski, B., \& Vanneman, R. (1997). All women benefit: The macro-Level effect of occupational integration on gender earnings equality. American Sociological Review, 62(5), 714-734.

Du, F., \& Dong, X. Y. (2013). Women's employment and childcare choices in urban China during the economic transition. Economic Development and Cultural Change, 62(1), 131-155.

England, P. (2010). The gender revolution: Uneven and stalled. Gender and Society, 24(2), 149-166.

$\mathrm{Gu}, \mathrm{H}$. (2013). The state, market and recurrence of traditional social gender concept. Academia, 6,104-114.

Hearle, C., \& Hu, D. F. (2019). China country brief: On gender equality and women's economic empowerment. London: UKAid/WOW.

Hochschild, A. R. (1989). The second shift: Working parents and the revolution at home. New York, NY: Avon Books.

Ji, Y., Wu, X. G., Sun, S., \& Guo, G. Y. (2017). Unequal care, unequal work: Toward a more comprehensive understanding of gender inequality in post-reform urban China. Sex Roles, 77(11/12), 765-778.

Jiang, Y. P. (2012). Duel construction of nation and family and women's gender role in China's "planned economy" period. Journal of Shandong Women College, 1 , 1-6.

Jin, Y. H. (2006). Rethinking of iron girls: Gender and la- bor in cultural revolution in China. Sociological Study, 1, 169-196.

Kang, R., \& Lv, X. J. (2016). A summary of the debate on the relationship between the universal two-childpolicy, childbearing intention and female employment. Theory Monthly, 12, 155-161.

Khayria, K., \& Feki, R. (2015). Gender inequality and economic development. Business and Economics Journal, 6. http://dx.doi.org/10.4172/21516219.1000180

Lewis, K. (2011). The gender dividend: A business case for gender equality. UN Women. Retrieved from http://www.unwomen.org/en/digital-library/ publications/2011/12/the-gender-dividend-abusiness-case-for-gender-equality

Li, C. L. (2016). "Male disadvantage," "left-over women" and difficulty in the job market of female college students: Challenges from the gender reversal in education. Journal of Chinese Women's Studies, 2, 33-39.

Li, X. J. (1997). What words do we use to think about women, and who makes words and endows them with meaning? Zhejiang Academic Journal, 4, 81-91.

List of members of the 19th Central Committee, alternate members and members of the Central Commission for discipline inspection. (2017, October 23). Xinhuanet. Retrieved from http://www.xinhuanet.com/ politics/19cpcnc/2017-10/24/c_1121848969.htm

Liu, A. Y. (2018). Institution, opportunity structure and gender attitude: How labor participation of urban married women being possible? Journal of Chinese Women's Studies, 6, 15-30.

Liu, Q. (2007). Several issues on improving employment statistics. Journal of Harbin Party School, 2, 43-44.

Liu, L. Q., \& Zhang, J. J. (2013). "Leftover women" and banquet: The phenomenon of "leftover women" in gender perspective and media communication strategy. Journal of Chinese Women Studies, 5, 76-82.

Liu, P. W., Meng, X., \& Zhang, J. (2000). Sectoral gender wage differentials and discrimination in the transitional Chinese economy. Journal of Population Economics, 13(2), 331-352.

Chairman Mao and Chairman Liu had a good swim in Ming Tomb reservoir. (1965). Renmin Newspaper. Retrieved from http://data.people.com.cn/ rmrb/19650527/1

Maurer-Fazio, M., Rawski, T. G., \& Zhang, R. W. (1999). Inequality in the rewards for holding up half the sky: Gender wage gaps in China's urban labor market, 1988-1994. The China Journal, 41, 55-88.

Meleis, A. I., \& Lindgren, T. G. (2002). Men work from sun to sun, but women's work is never done: Insights on research and policy. Health Care for Women International, 23, 742-753.

National Statistical Bureau. (2003). Men and women in Chinese society: Facts and figures. Beijing: China Statistics Press.

National Statistical Bureau. (2007). National one percent 
population survey of 2005 in China. Beijing: China Statistics Press.

National Statistical Bureau. (2012). Men and women in Chinese society: Facts and figures. Beijing: China Statistics Press.

National Statistical Bureau. (2016a). The 2015 national one percent population survey data. Yearbook China. Retrieved from https://www.yearbookchina. com/navibooklist-N2017060068-2.html

National Statistical Bureau. (2016b). China population and employment statistics yearbook. Beijing: China Statistics Press.

Pagés, C., \& Piras, C. (2010). The gender dividend: Capitalizing on women's work. Washington, DC: I-ADB Publications.

Qing, S. S. (2019). Social and cultural roots of gender income gap in China: An empirical analysis based on gender roles. Sociological Studies, 1, 106-131.

Shi, F. L. (2009). Gender and the current status, problems and reason of women's political participation in China. Work Union Forum, 15(2), 23-25.

Shu, X., \& Bian, Y. (2003). Market transition and gender gap in earnings in urban China. Social Forces, 81(4), 1107-1145.

Song, S. P. (2011). "Home" or "be Homed"? "Women's going home" in the process of marketization and the transformation of ideology in Chinese society. Journal of Chinese Women Studies, 4, 5-12.

Song, X., \& Zhen, G. (2013). An investigation of Chinese women's social status. Beijing: Chinese Women Press.

State Council Information Office. (2015). Gender equality and women's development in China. State Council Information Office. Retrieved from http:// www.scio.gov.cn/zfbps/ndhf/2015/Document/ 1449894/1449894.htm

Statista. (2020). Percentage of GDP contributed by female workers, as of 2015, by region. Statista. Retrieved from https://www.statista.com/statistics/ 523838/women-share-of-gdp-region

Stockman, N., Bonney, N., \& Sheng, X. W. (1995). Women's work in East and West: The dual burden of employment and family life. Armonk, NY: M. E. Sharpe.

The Central People's Government of the PRC. (2005). Constitution of the People's Republic of China. Beijing: The Central People's Government of the PRC. Retrieved from http://www.gov.cn/govweb/test/200506/14/content_6310.htm

The Central People's Government of the PRC. (2019). A report released by the National Bureau of Statistics shows that China's urbanization rate has increased significantly in 70 years. Central People's Government of the PRC. Retrieved from http://www.gov.cn/ shuju/2019-08/16/content 5421576.htm

The proportion of women in CPPCC and NPC has reached a new high. (2018, February 24). Xinhua News.

The World Bank. (n.d.). Labor force participation rate, male (\% of male population ages $15+$ )-China. The World Bank. Retrieved from https://data.worldbank.
org/indicator/SL.TLF.CACT.MA.ZS?locations=CN

UNDP. (2019). United Nations: World population data outlook 2019. 199/T. Retrieved from http://www. 199it.com/archives/896468.html

Vanham, P. (2018, April 12). Women in China contribute more to GDP than in the US. Viewing them as 'leftover' is problematic. We Forum. Retrieved from https://www.weforum.org/agenda/2018/04/ women-in-china-contribute-more-to-gdp-than-inthe-us-viewing-them-as-leftover-is-problematic

World Economic Forum. (2019). Global gender gap report 2018. World Economic Forum. Retrieved from http://reports.weforum.org/global-gender-gapreport-2018

Wu, X. Y. (2009). Change of gender discourse in the context of marketization. Social Science in China, 2, 163-176.

Xi, J. (2015, September 28). Promote women's all-round development in order to build and share a better world: Speech at the Global Women's Summit. Xinhua News. Retrieved from http://www.xinhuanet. com/politics/2015-09/28/c_128272780.htm

Yan, J. J. (2018). Political participation of women in China in the perspective of gender (Unpublished Master dissertation). Chunyu Dong, Liaoning Normal University, Dalian, Liaoning Province.

Yang, J. H. (2010). Gender equality in China revisited: Theory and reflections. Journal of Chinese Women Studies, 6, 5-18.

Yang, J. H. (2017). Fertility policy and family change in China. Open Times, 3, 12-26.

Yang, J. H. (2018). Supply-side reform and childcare service for children under age three. Social Sciences, 9, 89-100.

Yang, J. H. (2019). "Double taxes of gender and motherhood" and female labor force participation. Population Research, 1, 38-53.

Yang, J. H., \& He, Z. H. (2014). Continuity or change: Family in transitional China. Population Research, 2, 38-53.

Yang, J. H., \& Li, H. J. (2014). Continuity or strategy: Gender pattern of division of household work in China between 1990-2010. Academic Research, 2, 31-41, 54.

Yang, J. H., \& Xie, Y. F. (2013). The situation of Chinese women's education. In X. H. Jiang, T. Lin, \& Y. P. Jiang (Eds.), In 2008-2013: China's gender equality and women's development report (pp. 42-58). Beijing: China Women Press.

Zhang, Y., \& Hannum, E. (2015). Diverging fortunes: The evolution of gender wage gaps for singles, couples and parents in China, 1989-2009. Chinese Journal of Sociology, 1(1), 15-55.

Zhu, C. Z., \& Li, S. Z. (1997). The double-edged effect of the one-child policy and women in China. Xian: Xian Transportation University Press.

Zuo, J. P. (2005). Women's liberation and gender equality in 1950s: Experiences and feelings of urban couples in China. Society, 1, 182-209. 


\section{About the Author}

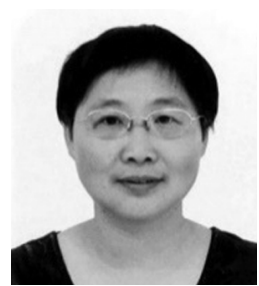

Juhua Yang graduated from the Department of Sociology at Brown University and is currently a Professor of Sociology at Minzu University of China. Her research focuses on social wellbeing and its articulation with social change. Recently published books include In Search of the Urban Dream in China (2018), Introduction to Social Demography (2016), Migration and Economic Integration (2013), Advanced Social Statistics in Stata (2012) and Population Change and Poverty among the Elderly (2011). She has also published numerous research articles on gender and family. 